\title{
Secondary polycythaemia with elevated carbon monoxide levels due to hookah pipe smoking: A public health concern
}

\author{
T Moodley, MB ChB, DTM\&H; K T Mannaru, MB BCh, MMed (Haem), FC Path (SA) Haem; A Hugo, MB BCh; J A Lines, MB ChB; \\ J M van der Merwe, MB ChB; N Ramparsad, MB BCh, MMed (Haem); N S Holland, MB BCh, FC Path (SA) Haem
}

Haematology Department, Lancet Laboratories, Johannesburg, South Africa

Corresponding author: T Moodley (trishamoodley@yahoo.com)

\begin{abstract}
Hookah pipe (HP) smoking is perceived as a harmless activity, enjoyed by young adults and high school-going children. Awareness of the health impact of recreational habits, and their intersection with new social norms in the COVID-era, requires critical review. We describe a case series of young HP smokers presenting with secondary polycythaemia with significant clinical sequelae necessitating extensive workup. HP smoking may lead to acute and chronic carbon monoxide intoxication, with resultant secondary polycythaemia and complications including provoked thrombosis.
\end{abstract}

S Afr Med J 2021;111(10):938-941. https://doi.org/10.7196/SAMJ.2021.v111i10.15802

Hookah pipe (HP) smoking, also known as hubbly bubbly, waterpipe shisha and narghile, has become a popular way of smoking tobacco over the past decade. ${ }^{[1]} \mathrm{HP}$ smoking was previously limited to older males in the Middle East, but has emerged as a trendy practice among youth all over the world, including South Africa (SA). ${ }^{[1]}$ A recent crosssectional study in Johannesburg, SA, showed that $\sim 26 \%$ of grade 8 and $70 \%$ of grade 12 learners have smoked an $\mathrm{HP}^{[2]}$ The current widespread use is attributable to lack of knowledge about the dangers of HP smoking, the popular café culture, and the availability of attractive flavours. ${ }^{[3]}$

Surveys suggest that many people perceive HP smoking as less harmful and less addictive than cigarette smoking, but this is not supported by the literature. ${ }^{[3]}$ Misperceptions include that inhaled smoke has been 'detoxified' by the 'filtering' effects of the water and that smoke from an HP contains less nicotine. There is also a lack of information in the media regarding the dangers of HP smoking. ${ }^{[3-5]}$ Behavioural patterns of tobacco smoking dependence have been observed among HP smokers, such as unsuccessful attempts to stop HP smoking, increased use of the HP, and habits to appease cravings. ${ }^{[3]}$ In view of the prolonged nature of an HP smoking session, the cumulative nicotine exposure is substantially higher than that of cigarette smoking. ${ }^{[6,7]}$ The HP apparatus is complex, and the manufacturing process is non-standardised, leading to variable exposure to smoke byproducts, as well as the harmful effects of second-hand HP smoke. There is also no known regulation of the composition of HP tobacco products. ${ }^{[7-10]}$

We present a case series of patients who underwent bone marrow investigations for polycythaemia, in whom chronic HP smoking was identified as the underlying cause. These patients represent an unusual secondary polycythaemia cohort in that they were young and a subpopulation had documented venous thromboembolism (VTE). The findings highlight some of the potential risks of HP smoking and the need to elicit a full smoking history. ${ }^{[11]}$

\section{Case presentation}

We describe 7 patients with secondary polycythaemia due to HP smoking, identified over a 2.5-year period (June 2018 - November
2020), from private hospitals in the Johannesburg area in SA. The clinical information in Table 1 was obtained from the treating doctors, and the laboratory data in Table 2 were collated from the access-controlled Meditech software system at Lancet Laboratories. Informed written consent was obtained from all the patients to use their information anonymously.

All the patients were male, with ages ranging from 28 to 47 years. Five of the patients presented with nonspecific symptoms and polycythaemia as an incidental finding. Two of the patients experienced a thromboembolic event.

The patients' HP smoking history ranged from 3 months to 12 years. All 7 patients smoked an HP on a daily basis, with the duration of the smoking sessions being 10 minutes to $\sim 3$ hours per day. The frequency of the smoking sessions was $2-5$ times per day. The hookah pack-year calculation estimated the cigarette consumption per HP smoking session to be between 19 cigarettes in a 15-minute session and 225 cigarettes in a 3 -hour session. The equivalent cigarette pack-year history ranged from 1 to 34 pack-years.

Laboratory investigations (Table 2) revealed an elevated red cell count and haemoglobin and haematocrit concentrations in all 7 patients, reflecting polycythaemia according to the reference ranges used. The white cell count and platelet values were not elevated. Carboxyhaemoglobin levels were available for 3 patients, 1 of which was in the toxic range (36.8\%) and the other 2 in the range of a cigarette smoker with a 1 - 2-year pack-year history. Serum ferritin levels were normal in 6 patients, but elevated in 1. Erythropoietin levels were lower than the reference interval in only 1 patient. The others were all in range.

Bone marrow investigations, performed in all the patients, revealed no morphological features to suggest a myeloproliferative neoplasm, and molecular investigations did not detect the JAK2 (Janus kinase 2) V617F mutation. Cytogenetic studies, performed on 3 of the patients, indicated a normal male chromosome pattern. Next-generation sequencing, performed on 2 of the patients, detected no fusions or somatic variants. In view of these findings, none of the cases meet the World Health Organization criteria for polycythaemia vera. ${ }^{[15]}$ 
Table 1. Patient clinical information

\begin{tabular}{|c|c|c|c|c|c|c|c|}
\hline & Patient 1 & Patient 2 & Patient 3 & Patient 4 & Patient 5 & Patient 6 & Patient 7 \\
\hline Age (years) & 28 & 29 & 29 & 47 & 28 & 31 & 34 \\
\hline Sex & M & M & M & $\mathrm{M}$ & $\mathrm{M}$ & $\mathrm{M}$ & $\mathrm{M}$ \\
\hline $\begin{array}{l}\text { Clinical } \\
\text { presentation }\end{array}$ & $\begin{array}{l}\text { Fever for } \\
3 \text { days, } \\
\text { pulmonary } \\
\text { emboli }\end{array}$ & $\begin{array}{l}\text { Lethargy, } \\
\text { progressive } \\
\text { polycythaemia }\end{array}$ & $\begin{array}{l}\text { Pruritus, chronic } \\
\text { urticaria } \\
\text { Blood donor }\end{array}$ & DVT left calf & Haematuria & $\begin{array}{l}\text { Pica, restless } \\
\text { legs }\end{array}$ & $\begin{array}{l}\text { Headache, } \\
\text { fatigue }\end{array}$ \\
\hline \multicolumn{8}{|l|}{$\begin{array}{l}\text { HP smoking } \\
\text { history }\end{array}$} \\
\hline Frequency & Daily & Daily $2-3 \times /$ day & Daily $2-3 \times /$ day & Daily $2 \times$ /day & $\begin{array}{l}\text { Daily } 2-3 \times / \text { day } \\
\text { Weekends } 3-5 \times\end{array}$ & $\begin{array}{l}\text { Daily } 3-5 \\
\times / \text { day }\end{array}$ & Daily \\
\hline $\begin{array}{l}\text { Duration/ } \\
\text { session }\end{array}$ & $\sim 45$ minutes & $\sim 60$ - 90 minutes & 35 minutes & $\sim 60$ minutes & $\sim 15$ minutes & $\begin{array}{l}\sim 30-45 \\
\text { minutes }\end{array}$ & $\begin{array}{l}\sim 180 \text { minutes } \\
\text { per day }\end{array}$ \\
\hline $\begin{array}{l}\text { History of HP } \\
\text { smoking }\end{array}$ & $>10$ years & $>5$ years & $>12$ years & 12 months & $>11$ years & 3 months & $\begin{array}{l}3 \text { years, stopped } \\
2 \text { months } \\
\text { before hospital } \\
\text { admission }\end{array}$ \\
\hline $\begin{array}{l}\text { Cigarette } \\
\text { smoking }\end{array}$ & None & Not known & Not known & None & $\begin{array}{l}2 \text { years, stopped } \\
10 \text { years ago }\end{array}$ & $\begin{array}{l}18 \text { years, } \\
\text { stopped } \\
2 \text { months } \\
\text { before } \\
\text { hospital } \\
\text { admission }\end{array}$ & None \\
\hline $\begin{array}{l}\text { HP pack-year } \\
\text { calculation }^{[12-14]}\end{array}$ & $\begin{array}{l}\sim 56 \text { cigarettes } \\
\text { per } 45 \text {-minute } \\
\text { session } \\
28 \text { cigarette } \\
\text { pack-year } \\
\text { equivalent }\end{array}$ & $\begin{array}{l}\sim 75 \text { cigarettes per } \\
60 \text {-minute session } \\
19 \text { cigarette pack- } \\
\text { year equivalent }\end{array}$ & $\begin{array}{l}\sim 44 \text { cigarettes per } \\
35 \text {-minute session } \\
26 \text { cigarette pack- } \\
\text { year equivalent }\end{array}$ & $\begin{array}{l}\sim 75 \\
\text { cigarettes per } \\
60 \text {-minute } \\
\text { session } \\
4 \text { cigarette } \\
\text { pack-year } \\
\text { equivalent }\end{array}$ & $\begin{array}{l}19 \text { cigarettes per } \\
15 \text {-minute session } \\
10 \text { cigarette pack- } \\
\text { year equivalent }\end{array}$ & $\begin{array}{l}56 \text { cigarettes } \\
\text { per } \\
45 \text {-minute } \\
\text { session } \\
1 \text { cigarette } \\
\text { pack-year } \\
\text { equivalent }\end{array}$ & $\begin{array}{l}\text { 225 cigarettes } \\
\text { per 3-hour } \\
\text { session } \\
34 \text { cigarette } \\
\text { pack-year } \\
\text { equivalent }\end{array}$ \\
\hline
\end{tabular}

Table 2. Laboratory investigations

\begin{tabular}{|c|c|c|c|c|c|c|c|}
\hline Variables (reference ranges) & Patient 1 & Patient 2 & Patient 3 & Patient 4 & Patient 5 & Patient 6 & Patient 7 \\
\hline \multicolumn{8}{|l|}{ FBC } \\
\hline $\operatorname{RCC}\left(4.5-6.5 \times 10^{12} / \mathrm{L}\right)$ & 6.80 & 6.28 & 7.33 & 7.46 & 6.22 & 6.25 & 6.73 \\
\hline $\mathrm{Hb}(13.8-18.8 \mathrm{~g} / \mathrm{dL})$ & 20.5 & 18.9 & 20.9 & 21.5 & 22.0 & 19.4 & 22.2 \\
\hline Hct $(0.40-0.56 \mathrm{~L} / \mathrm{L})$ & 0.60 & 0.53 & 0.62 & 0.65 & 0.60 & 0.55 & 0.61 \\
\hline $\operatorname{MCV}(79-100 \mathrm{fL})$ & 88 & 84.2 & 84.3 & 86.6 & 95 & 87.5 & 90 \\
\hline WCC $\left(4.0-12.0 \times 10^{9} / \mathrm{L}\right)$ & 2.34 & 6.44 & 10.15 & 6.45 & 5.0 & 7.09 & 4.22 \\
\hline Platelet count $\left(150-450 \times 10^{9} / \mathrm{L}\right)$ & 120 & 227 & 263 & 169 & 210 & 260 & 206 \\
\hline $\mathrm{BG}$ and $\mathrm{COHb}(\%)^{*}$ & $\begin{array}{l}\text { Not performed } \\
\text { on hospital } \\
\text { admission }\end{array}$ & $\begin{array}{l}\text { COHb-BG } \\
\text { instrument } \\
\text { unable to } \\
\text { calculate } \\
\text { parameter (see } \\
\text { 'Discussion') }\end{array}$ & $\begin{array}{l}\text { Not } \\
\text { performed } \\
\text { on hospital } \\
\text { admission }\end{array}$ & $\begin{array}{l}\text { Not } \\
\text { performed } \\
\text { on hospital } \\
\text { admission }\end{array}$ & $\begin{array}{l}\mathrm{COHb} \\
36.8\end{array}$ & $\begin{array}{l}\text { First: BG } \\
\text { normal with } \\
\text { no COHb } \\
\text { measured } \\
\text { Second: BG } \\
\text { done } 1 \text { month } \\
\text { after stopping } \\
\text { HP smoking. } \\
\text { ONLY COHb } \\
\text { was measured } \\
\text { (4.4) }\end{array}$ & $\begin{array}{l}\text { COHb } 3.8 \\
\text { Stopped HP } \\
\text { smoking } \\
2 \text { months } \\
\text { before } \\
\text { hospital } \\
\text { admission }\end{array}$ \\
\hline Serum ferritin $(20-300 \mathrm{ng} / \mathrm{mL})$ & Not done & 207 & 112 & Not done & 145 & 18 & 599 \\
\hline Erythropoietin (4.3 - $29 \mathrm{mIU} / \mathrm{mL})$ & 4.6 & 8.2 & 22 & Not done & 3.3 & 11.4 & 13.7 \\
\hline
\end{tabular}


Table 3. Radiological investigations

\begin{tabular}{|c|c|c|c|c|c|c|c|}
\hline Investigation & Patient 1 & Patient 2 & Patient 3 & Patient 4 & Patient 5 & Patient 6 & Patient 7 \\
\hline CT scan & $\begin{array}{l}\text { CT chest angiogram: } \\
\text { small filling defects } \\
\text { in descending } \\
\text { pulmonary arteries } \\
\text { suggestive of } \\
\text { thromboemboli }\end{array}$ & $\begin{array}{l}\text { Not } \\
\text { performed }\end{array}$ & $\begin{array}{l}\text { Not } \\
\text { performed }\end{array}$ & $\begin{array}{l}\text { Not } \\
\text { performed }\end{array}$ & Not performed & $\begin{array}{l}\text { Not } \\
\text { performed }\end{array}$ & $\begin{array}{l}\text { Not } \\
\text { performed }\end{array}$ \\
\hline CXR & Not performed & $\begin{array}{l}\text { Not } \\
\text { performed }\end{array}$ & $\begin{array}{l}\text { Not } \\
\text { performed }\end{array}$ & $\begin{array}{l}\text { Not } \\
\text { performed }\end{array}$ & $\begin{array}{l}\text { Hyperinflation, } \\
\text { prominent vessels } \\
\text { in pulmonary } \\
\text { hilum, coarse } \\
\text { bronchovascular } \\
\text { markings in lung } \\
\text { bases }\end{array}$ & $\begin{array}{l}\text { Normal } \\
\text { findings }\end{array}$ & $\begin{array}{l}\text { Normal } \\
\text { findings }\end{array}$ \\
\hline $\begin{array}{l}\text { Venous Doppler } \\
\text { US }\end{array}$ & Not performed & $\begin{array}{l}\text { Not } \\
\text { performed }\end{array}$ & $\begin{array}{l}\text { Not } \\
\text { performed }\end{array}$ & $\begin{array}{l}\text { Positive for } \\
\text { DVT }\end{array}$ & Not performed & $\begin{array}{l}\text { Not } \\
\text { performed }\end{array}$ & $\begin{array}{l}\text { Not } \\
\text { performed }\end{array}$ \\
\hline Abdominal US & Normal spleen size & $\begin{array}{l}\text { Normal } \\
\text { spleen size }\end{array}$ & $\begin{array}{l}\text { Normal } \\
\text { spleen size }\end{array}$ & $\begin{array}{l}\text { Not } \\
\text { performed }\end{array}$ & Normal spleen size & $\begin{array}{l}\text { Normal } \\
\text { spleen size }\end{array}$ & $\begin{array}{l}\text { Normal } \\
\text { spleen size }\end{array}$ \\
\hline
\end{tabular}

Radiological investigations (Table 3) confirmed the thromboembolic events in 2 patients (patients 1 and 5). The chest radiographs performed indicated normal lung features in 2 of the patients, and showed hyperinflation with prominent hilar pulmonary vessels in 1 patient.

No causes of secondary polycythaemia other than HP smoking were identified.

\section{Discussion}

The patients in this series illustrate the potential adverse effects of HP smoking, which include acute carbon monoxide intoxication, thromboembolic events, and secondary polycythaemia.

\section{Carbon monoxide toxicity}

The secondary polycythaemia caused by HP smoking develops as a result of tissue hypoxia from chronic exposure to elevated levels of carbon monoxide (CO). $\mathrm{CO}$ is a product of the ignited charcoal used to heat the tobacco in the water pipe, and studies have shown plasma levels of carboxyhaemoglobin to be 10 times higher than those observed in cigarette smokers. ${ }^{[16]}$

Acute CO intoxication is also a possibility. This is associated with a left shift of the oxygen-dissociation curve due to hypoxia. The elevated CO levels cause mitochondrial dysfunction at a cellular level, resulting in myocardial and neuronal necrosis. ${ }^{[17]}$ This process explains the acute cardiac and neurological symptoms that patients develop. Symptoms and signs can be nonspecific and include loss of consciousness and confusion, headache, malaise and nausea. Severe cases may result in seizures, coma, acute myocardial ischaemia and ventricular arrhythmias. ${ }^{[7,16]}$

The carboxyhaemoglobin levels measured in our case series were quantified on a point-of-care instrument available at Lancet Laboratories, using a lithium heparinised whole-blood sample transported on ice to the laboratory ${ }^{[18]}$ The carboxyhaemoglobin level is a calculated parameter, calibrated on the point-of-care instrument, and is part of the co-oximetry function of the blood gas instrument. Availability of this function should be confirmed with the laboratory used. Co-oximetry evaluates the total haemoglobin and determines the percentage of functional (e.g. oxyhaemoglobin) and dysfunctional haemoglobin species such as carboxyhaemoglobin and methaemoglobin. ${ }^{[18]}$ Heparinised syringes and blood tubes can be used for blood gas and carboxyhaemoglobin analysis using small volumes (microlitres) of arterial, venous or capillary blood, but are subject to pre-analytical and analytical variables. ${ }^{[19]}$ These blood samples are stable at room temperature for up to a month at $22^{\circ} \mathrm{C}$ and refrigerated for several years at $4^{\circ} \mathrm{C}{ }^{[20,21]}$

\section{Thromboembolic risk}

Although our cohort is small, 2 of our patients (28\%) presented with a VTE (pulmonary emboli and lower-limb deep-vein thrombosis). Secondary polycythaemia from any cause has been associated with an increased risk of thrombosis. In addition, acute exposure to HP smoke in animal models demonstrated platelet activation and thrombogenesis. ${ }^{[1,16]}$

\section{Secondary polycythaemia}

Erythrocytosis results in increased blood viscosity. Symptoms of hyperviscosity include headaches, visual disturbances, dyspnoea, abnormal bleeding and severe neurological fall-out such as seizures and coma. These symptoms are alleviated by therapeutic venesection. ${ }^{[16]}$

\section{Other adverse effects}

Non-haematological effects associated with HP smoking include nicotine addiction; exposure to other carcinogens; infection risk (e.g. SARS-CoV-2, herpesvirus, Epstein-Barr virus) by means of a shared mouthpiece, as well as the water in the bowl of the HP apparatus acting as a reservoir for bacterial, mycobacterial and fungal growth; oral and gastrointestinal sequelae such as periodontal disease and oesophageal reflux disease; and cardiovascular and/or cardiopulmonary changes akin to those described with cigarette smoking. ${ }^{[6,7,22,23]}$ Effects in pregnancy have been documented to increase the risk of intrauterine growth restriction and preterm labour. ${ }^{[11,24]}$

The perceived harmlessness of HP smoking has resulted in children, adolescents and young adults of all socioeconomic backgrounds increasingly adopting this dangerous but seemingly socially acceptable practice. In view of these misconceptions, there is a need for increased public awareness and education on the adverse effects of HP smoking to prevent an additional burden on our already pressured healthcare system. ${ }^{[23-26]}$ 


\section{Teaching points}

- HP tobacco products do not appear to be under the same regulatory scrutiny as traditional tobacco products, which requires review.

- HP-related polycythaemia should be considered in the younger patient with nonspecific symptoms.

- Recreational history is important. Smoking is no longer limited to cigarettes, and a full smoking history should include HP smoking. A calculator for HP pack-year history is available online. ${ }^{[12]}$

- In the event of a thromboembolic presentation, exclusion of polycythaemia is recommended in addition to eliciting the traditional risk factors and family history.

- A formal carboxyhaemogloblin measurement, or blood gas co-oximetry that is quality controlled, is recommended in the evaluation of polycythaemia, together with the patient history.

\section{Declaration. None.}

Acknowledgements. We thank the following doctors for their contribution to the write-up of the case series: Dr Lucille Singh, Dr Mohammed Arbee, Dr Adnaan Variava, Dr Lebogang Moja, Dr Robin C Ballantine and Dr Khethiwe Nyuswa, as well as our colleagues Dr Peter Tsaagane and Dr Ryan Benjamin from the Chemical Pathology Department at Lancet Laboratories for their knowledgeable recommendations.

Author contributions. Case series conceptualised by KTM, TM, AH, JAL, JMvdM. Data analysis: TM, AH, JAL, JMvdM. Writing, review and editing: TM, AH, JAL, JMvdM, KTM, NR, NSH. All the authors read and approved the manuscript.

\section{Funding. None.}

\section{Conflicts of interest. None.}

1. Kader Z, Roman NV, Crutzen R. Systematic review of interventions aimed at reducing hookah pipe use: Implications for practitioners and clinicians. S Afr Med J 2019;109(6):392-406. https://do org/10.7196/SAMJ.2019.v109i6.013892

2. Naicker N, Teare J, Albers P, et al. Prevalence of hookah pipe smoking in high-school learners in Johannesburg, South Africa. S Afr Med J 2020;110(6):546-551. https://doi.org/10.7196/SAMJ.2020. v110i6.14333

3. Maziak W. The waterpipe: A new way of hooking youth on tobacco. Am J Addict 2014;23(2):103-107. Maziak W. The waterpipe: A new way of hooking $y$
https://doi.org/10.1111/j.1521-0391.2013.12073.x

4. Akl EA, Ward KD, Bteddini D, et al. The allure of the waterpipe: A narrative review of factors affecting the epidemic rise in waterpipe smoking among young persons globally. Tob Control 2015;24(Suppl 1):i13-i21. https://doi.org/10.1136/tobaccocontrol-2014-051906

5. Akl EA, Jawad M, Lam WY, Co CN, Obeid R, Irani J. Motives, beliefs and attitudes towards waterpipe tobacco smoking: A systematic review. Harm Reduct J 2013;10(1):12-21. https://doi.org/10.1186/1477 $7517-10-12$
6. Blachman-Braun R, del Mazo-Rodríguez RL, López-Sámano G, Buendía-Roldán I. Hookah, is it really harmless? Respir Med 2014;108(5):661-667. https://doi.org/10.1016/.rmed.2014.01.013

7. Aslam HM, Saleem S, German S, Qureshi WA. Harmful effects of shisha: Literature review. Int Arch Med 2014;7(1):16-24. https://doi.org/10.1186/1755-7682-7-16

8. Tobacco Control Laws. Legislation by country: South Africa. https://www.tobaccocontrollaws.org/ legislation/country/south-africa/summary (accessed 15 March 2021).

9. World Health Organization Study Group on Tobacco (TobReg). TobReg Advisory Note. Waterpipe tobacco smoking: Health effects, research needs and recommended actions by regulators. Geneva: WHO, 2005. https://www.who.int/tobacco/global_interaction/tobreg/Waterpipe\%20 recommendation_Final.pdf (accessed 3 April 2021).

10. Qasim H, Alarabi AB, Alzoubi KH, Karim ZA, Alshbool FZ, Khasawneh FT. The effects of hookah/ waterpipe smoking on general health and the cardiovascular system. Environ Health Prev Med 2019;24(1):58-74. https://doi.org/10.1186/s12199-019-0811-y

11. Alarabi AB, Karim ZA, Montes Ramirez JE, et al. Short-term exposure to waterpipe/hookah smoke triggers a hyperactive platelet activation state and increases the risk of thrombogenesis. Arterioscler Thromb Vasc Biol 2020;40(2):335-349. https://doi.org/10.1161/atvbaha.119.313435

12. Royal College of General Practitioners. Smoking pack years calculator. https://www. smokingpackyears.com/ (accessed 9 December 2020).

13. Masters N, Tutt C, Yaseen N. Waterpipe tobacco smoking and cigarette equivalence. Br J Gen Pract 2012;62(596):127. https://doi.org/10.3399/bjgp12x631231

14. Shihadeh A, Azar S, Antonios C, Haddad A. Towards a topographical model of narghile waterpipe café smoking: A pilot study in a high socioeconomic status neighborhood of Beirut, Lebanon. pipe café smoking: A pilot study in a high socioeconomic status neighborhood of Beiru,

15. Thiele J, Kvasnicka HM, Orazi A, Tefferi A, Birgegård G, Barbui T. Polycythaemia vera. In: WHO Classification of Tumours of Haemopoietic and Lymphoid Tissues. International Agency for Research on Cancer (IARC), 2017:39-43.

16. Smith G, Mehta KD, Bhatt VR. Secondary polycythemia and the risk of venous thromboembolism (VTE) among hospitalized patients in the United States. Blood 2016;128(22):1427. https://doi. org/10.1182/blood.v128.22.1427.1427

17. Von Rappard J, Schönenberger M, Bärlocher L. Carbon monoxide poisoning following use of a waterpipe/hookah. Dtsch Arztebl Int 2014;111:674-679. https://doi.org/10.3238/arztebl.2014.0674

18. GEM Premier 5000 Operator's Manual. Revision 2, January 2017. https://www.exeterlaboratory. com/wp-content/uploads/SOP-GEM-5000-GAS-MACHINE-SOP-ed1.pdf (accessed 3 April 2021).

19. Touger M, Gallagher EJ, Tyrell J. Relationship between venous and arterial carboxyhaemoglobin . Touger M, Gallagher EJ, Tyrell J. Relationship between venous and arterial carboxyhaemoglobin
levels in patients with suspected carbon monoxide poisoning. Ann Emerg Med 1995;25(4):481-483. https://doi.org/10.1016/s0196-0644(95)70262-8

20. Fotouh Ghanem AAAE, Rahman RHA, Shabka OA. Stability of carboxyhaemoglobin in blood samples at different periods and temperatures: A forensic and toxicological tool for diagnosis. J Clin Toxicol 2012;2(8):144-147. https://doi.org/10.4172/2161-0495.1000144

21. Seto Y, Kataoka M, Tsuge K. Stability of blood carbon monoxide and hemoglobins during heating. Forensic Sci Int 2001;121(1-2):144-150. https://doi.org/10.1016/s0379-0738(01)00465-0

22. World Health Organization. Tobacco free initiative. Tobacco and waterpipe use increases the risk of COVID-19. http://www.emro.who.int/tfi/know-the-truth/tobacco-and-waterpipe-users-are-atincreased-risk-of-covid-19-infection.html (accessed 31 May 2021).

23. Chaouachi K. Hookah (shisha, narghile) smoking and environmental tobacco smoke (ETS): A critical review of the relevant literature and the public health consequences. Int J Environ Res Public Health 2009;6(2):798-843. https://doi.org/10.3390/ijerph6020798

24. World Health Organization. WHO factsheet: Waterpipe smoking and health. 2015. https://www. who.int/tobacco/publications/prod_regulation/factsheetwaterpipe/en/ (accessed 15 March 2021).

25. Hoffman AC, Salgado RV, Dresler C, Faller RW, Bartlett C. Flavour preferences in youth versus adults: A review. Tob Control 2016;25(Suppl 2):ii32-ii39. https://doi.org/10.1136/ tobaccocontrol-2016-053192

26. Arshad A, Matharoo J, Arshad E, Sadhra SS, Norton-Wangford R, Jawad M. Knowledge, attitudes, and perceptions towards waterpipe tobacco smoking amongst college or university students: and perceptions towards waterpipe tobacco smoking amongst college or university students:
A systematic review. BMC Public Health 2019;19(1):439-450. https://doi.org/10.1186/s12889-019$6680-x$

Accepted 21 June 2021. 